\title{
PENGARUH BERBAGAI MACAM PENDINGINAN DAN PENGEMASAN TERHADAP UMUR SIMPAN JAGUNG MANIS (Zea mays saccharata)
}

\author{
(The Influence of Cooling and Packing on Storage Life of Sweet Corn \\ (Zea mays saccharata)) \\ Rustiningsih, Nafi Ananda Utama, Innaka Ageng Rineksane \\ Program Studi Agronomi Fakultas Pertanian Universitas Muhammadiyah Yogyakarta \\ Jl. Lingkar Barat, Tamantirto, Kasihan, Yogakarta 55183
}

\begin{abstract}
This research was aimed to study the influence of kinds of cooling and packing on the storage life of sweetcorn in order to obtain the simple postharvest technology and easy to practice. The research was done during the February - March of 2005 in the Research Laboratory of Agriculture Faculty, Muhammadiyah University of Yogyakarta. The reducing sugar analysis was done in the Agriculture Technology Faculty of Gadjah Mada University.

The laboratory experiment was arranged ini $2 \times 3$ factorial completely randomized design with three replications. The cooling first factor was refrigerated in refrigerator to be compared to the hydro-cooling. Meanwhile, the polypropilene and polyethylene packaging were tested and compared to the unpackaged one. The flavor, reducing sugar, water content, percentage of nonconsumable part of sweetcorn, fresh weight of ears, and organoleptic properties were observed.

The result showed that there was no significantly interaction between cooling and packaging on the storage life and quality of sweet corn. The cooling treatment was significantly influenced the starch and reducing sugar level as well as the packaging treatment. Refrigeration storage could significantly keep the level of reducing sugar to remain higher than the hydro-cooling, this treatment was also decreased the starch content, decreased the proportion of unconsumable part, and maintained the flavor. The polyethylene packaging significantly keep the level of reducing sugar to remain higher and relatively maintained the flavor than the polypropilene packaging or unpackaged, but decreased the portion of unconsumable part.
\end{abstract}

Keywords : cooling, packing, storage life, sweet corn

\section{PENDAHULUAN}

Jagung manis pertamakali dikenal masyarakat Indonesia dalam bentuk kalengan, pada awal tahun 1980-an mulai ditanam untuk kebutuhan hotel, restoran dan swalayan.Dengan semakin bertambahnya permintaan jagung manis maka semakin banyak yang mengusahakan (Koeswara 1982). Keunggulan jagung manis apabila direbus memiliki rasa manis, enak, mengandung sumber hidrat arang dan memiliki kalori yang hampir sama dengan kalori yang terkandung dalam pati (Zakariya, 2001). Permintaan jagung manis yang cukup besar dengan harga yang tinggi dan keadaan segar, mendorong untuk mengembangkan jagung manis khususnya dalam penanganan perlakuan pascapanen. Kelemahan utama jagung manis adalah cepat terjadinya penurunan rasa manis setelah dilakukan pemanenan. Kader (1995) menyatakan adanya respirasi dapat menyebabkan bahan kehilangan substrat. Pengurangan susbtrat dalam respirasi menyebabkan hilangnya sumber energi dan menurunkan kualitas flavor, terutama rasa manis, oleh karena itu perlu dilakukan upaya-upaya penanganan pasca panen yang tepat sehingga laju penurunan rasa manis dari jagung manis dapat ditekan dan waktu pemasarannya menjadi lebih panjang. 
Suhu yang tinggi dapat bersifat merusak mutu simpan sayuran dan buah-buahan, akan tetapi kenaikan suhu produk tidak dapat dihindarkan terutama jika pemanenan dilakukan selama hari yang panas (Muchtadi, 1992). Hydro-cooling adalah membasahi seluruhnya atau membenamkan di dalam air beku. Hydro-cooling ini efektif dalam pemindahan panas pada jagung manis setelah panen, karena tingkat pemindahan kalor adalah sebanding dengan perpindahan temperatur. Temperatur yang tepat untuk pendinginan Hydro-cooling adalah $4^{\circ} \mathrm{C}$ ( Anonim, 2004). Hydrocooling dimaksudkan untuk memperlambat respirasi, menurunkan kepekaan terhadap mikrobia, mengurangi jumlah air yang hilang. Untuk memperpanjang umur simpan selain dengan perlakuan pendinginan dapat juga dilakukan dengan pengemasan.

Pengemasan buah dalam plastik merupakan metode yang paling umum untuk memperpanjang masa simpan buah. Di dalam plastik akan timbul udara termodifikasi, karena terbatasnya $\mathrm{O}_{2}$ dan meningkatnya $\mathrm{CO}_{2}$, sehingga kecepatan respirasi dan transprasi menjadi tehambat yang selanjutnya memperlambat pematangan dan memperpanjang umur simpan. Tujuan penelitian ini adalah untuk mengetahui dan mendapatkan metode pendinginan dan jenis pengemas yang dapat memperpanjang umur simpan jagung manis

\section{BAHAN DAN METODE PENELITIAN}

Penelitian dilaksanakan mulai Februari sampai Maret 2005 di Laboratorium Penelitian Universitas Muhammadiyah Yogyakarta, dan untuk analisis kadar gula dan pati dilakukan di laboratorium biokimia Universitas Gajah Mada.

Bahan yang digunakan adalah jagung manis yang diperoleh dari kecamatan Seyegan Sleman Yogyakarta, air es, plastik polietilen, plastik polipropilen, label, dan bahan-bahan untuk analisis kimia. Alat yang digunakan adalah fruit penetrometer, oven, timbangan elektrik, dan alat-alat untuk analisis kimia.

Penelitian dilakukan dengan mengunakan metode percobaan laboratorium $2 \times 3$ faktorial yang disusun dalam Rancangan Acak Lengkap (RAL). Faktor pertama pendinginan terdiri atas dua aras yaitu pendinginan dalam refrigerator dan Hydro-cooling. Faktor kedua adalah macam pengemas yang terdiri atas tiga aras yaitu tanpa pengemas, pengemasan dengan plastik polipropilen, pengemasan polietilen. Masing-masing perlakuan diulang $3 \mathrm{kali}$ sehingga diperoleh 12 unit percobaan.

Sebelum diberi perlakuan jagung manis yang telah dipanen disortir, dipotong pada ujungnya, sebagian dikemas dan dimasukkan refigerator dan yang sebagian di masukkan dalam air es kemudian dikemas sesuai perlakuan. Pengamatan awal dilakukan terhadap berat buah, kadar air, persentase buah layak konsumsi, kadar gula reduksi, kadar pati, dan uji organoleptik, selanjutnya kemudian disimpan selama 7 hari. Pengukuran terhadap kadar pati, kadar gula reduksi, kadar air, persentase kerusakan buah, susut berat,kenampakan fisik serta uji organoleptik dilakukan selama masa penyimpanan .

\section{HASIL ANALISIS DAN PEMBAHASAN}

Produk hortikultura merupakan bagian dari organisme hidup yang masih mengalami perubahan kimiawi dan biokimiawi yang disebabkan oleh aktifitas metabolisme (Apandi, 1984). Jagung manis merupakan salah satu produk hortikultura yang mudah mengalami penurunan kualitas akibat tingginya aktivitas biokimia ketika dipetik. Selama penyimpanan juga terjadi perubahan-perubahan kimiawi dan fisiologis pada jagung manis.

\section{Kadar Pati}

Metabolisme pati mempunyai peranan penting pada perubahan yang terjadi dalam buah-buahan, sayur-sayuran selama proses penyimpanan dan pengolahan (Tranggono dan Sutardi, 1989).

Kadar pati diamati untuk mengetahui seberapa besar perubahan gula menjadi pati pada masing-masing perlakuan sehingga diketahui perubahan gula menjadi pati yang paling rendah. Hasil pengamatan rerata kadar pati dapat dilihat pada tabel 1 .

Tabel 1. Rerata kadar pati 6 hari setelah penyimpanan (\%)

\begin{tabular}{|c|c|c|c|c|}
\hline \multirow[b]{2}{*}{ Macam Pendinginan } & \multicolumn{3}{|c|}{ Mecam Pengernusan } & \multirow[b]{2}{*}{ Rerata } \\
\hline & $\begin{array}{c}\text { Tanpe } \\
\text { Pengemasan } \\
\text { (BO) }\end{array}$ & $\begin{array}{l}\text { Polipropilen } \\
\text { (B1) }\end{array}$ & $\begin{array}{l}\text { Polietilen } \\
\text { (B2) }\end{array}$ & \\
\hline $\begin{array}{l}\text { Refigenaror (AD) } \\
\text { Hydro-cooling (AD) }\end{array}$ & $\begin{array}{l}14,99 \\
18,75\end{array}$ & $\begin{array}{l}13,58 \\
15,94\end{array}$ & $\begin{array}{l}10,53 \\
14,42\end{array}$ & $\begin{array}{l}13,07 \mathrm{p} \\
16,37 \mathrm{q}\end{array}$ \\
\hline Rerata & $16,87 \mathrm{a}$ & $14,82 \mathrm{ab}$ & $12,48 \mathrm{~b}$ & $(-)$ \\
\hline
\end{tabular}

Keterangan : Nilai rerata yang diikuti huruf sama menunjukkan tidak berbeda nyata pada uji jarak Duncan pada taraf nyata 95\%. Tanda ( - ) menunjukkan tidak ada interaksi antar perlakuan.

Hasil sidik ragam kadar pati pada hari ke-6 menunjukkan bahwa tidak ada interaksi antara perlakuan pendinginan (A) dan perlakuan pengemasan (B). Namun perlakuan pendinginan (A) dan pengemasan $(B)$ berpengaruh nyata terhadap kadar pati jagung manis. Dari nilai rerata kadar pati jagung manis pada tabel 1 dapat diketahui bahwa perlakuan Refrigerator (A0) memiliki nilai yang lebih rendah yaitu sebesar $13,069 \%$, sedangkan jagung manis dengan perlakuan hydro-cooling (A1) memiliki rerata 
kadar pati yang lebih tinggi yaitu sebesar $16,37 \%$. Hal ini disebabkan karena pada perlakuan pendinginan dengan refrigerator mampu menghambat aktivitas enzim UDPG-fruktosa transglikosilase dan enzim UDPG pati-glukosil-transferase yang mampu menghambat perubahan gula menjadi pati pada jagung manis. Setiap penurunan suhu $10^{\circ} \mathrm{C}$ kecepatan reaksi akan berkurang 2 kali lipat, dan enzim akan bekerja optimal pada suhu $25^{\circ} \mathrm{C}-35^{\circ} \mathrm{C}$. Proses sintesa pati dari gula sederhana merupakan suatu reaksi enzimatis, maka oksidasi gula-gula sederhana menjadi pati terhambat dan kandungan patinya menjadi lebih sedikit.

Hasil analisis kadar pati pada tabel 1 menunjukkan bahwa perlakuan pengemasan (B) dapat menekan kadar pati jagung manis secara nyata. Hal ini dapat dilihat pada perlakuan tanpa kemas (B0) memiliki kadar pati yang tertinggi yaitu $16,87 \%$ yang berbeda nyata dengan perlakuan lainnya. Kadar pati terendah didapatkan pada perlakuan pengemasan polietilen yaitu $12,47 \%$. Hal ini disebabkan karena pada jenis pengemas polietilen mempunyai permeabilitas yang rendah terhadap $\mathrm{CO}_{2}$ dan $\mathrm{O}_{2}$ sehingga sulit berhubungan dengan udara luar kemasan. Kadar pati jagung manis secara umum pada awal penyimpanan mengalami penurunan, selanjutnya mengalami peningkatan seiring dengan lamanya penyimpanan seperti terlihat pada gambar 1 dan 2.

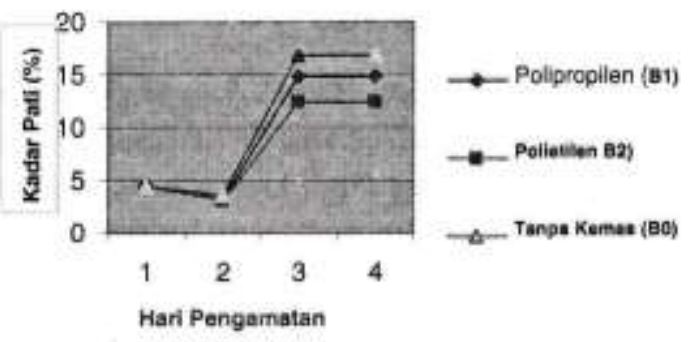

Gambar 1. Pengaruh pengemasan terhadap kadar pati

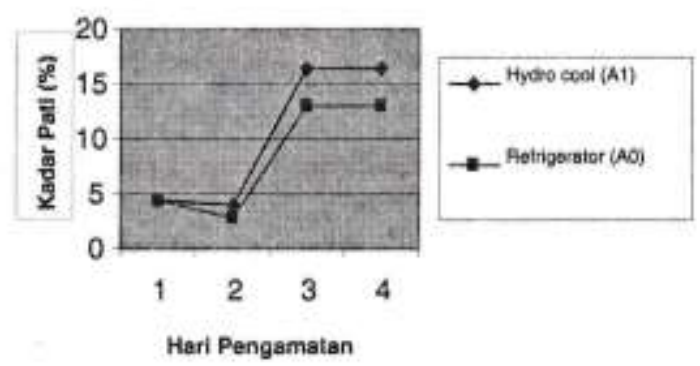

Gambar 2. Pengaruh pendinginan terhadap kadar pati

\section{Kadar Gula Reduksi}

Kadar gula reduksi diamati untuk mengetahui seberapa besar tingkat penurunan kadar gula selama penyimpanan. Hasil sidik ragam kadar gula reduksi disajikan pada tabel 2 .

Tabel 2. Rerata kadar gula reduksi 6 hari setelah disimpan (\%)

\begin{tabular}{|l|c|c|c|c|}
\hline \multirow{2}{*}{ Macam Pendinginan } & \multicolumn{3}{|c|}{ Macam Pengemasan } & \multirow{2}{*}{ Rerata } \\
\cline { 2 - 4 } & $\begin{array}{c}\text { Tanpa } \\
\text { Pengemasan } \\
(\mathrm{B} 0)\end{array}$ & $\begin{array}{c}\text { Polipropilen } \\
(\mathrm{B} 1)\end{array}$ & $\begin{array}{c}\text { Poliesilen } \\
\text { (B2) }\end{array}$ & \\
\hline Refigerator $(\mathrm{A0})$ & 0,113 & 0,125 & 0,183 & $0,140 \mathrm{q}$ \\
Hydro-cooling (A1) & 0,074 & 0,075 & 0,125 & $0,091 \mathrm{p}$ \\
\hline Rerata & $0,0935 \mathrm{e}$ & $0,1 \mathrm{~b}$ & $0,154 \mathrm{a}$ & $(-)$ \\
\hline
\end{tabular}

Keterangan : Nilai rerata yang diikuti huruf sama menunjukkan tidak berbeda nyata pada uji jarak Duncan pada taraf nyata $95 \%$. Tanda (-) menunjukkan tidak ada interaksi antar periakuan.

Hasil sidik ragam kadar gula reduksi jagung manis pada hari ke-4 menunjukkan bahwa tidak ada interaksi antar perlakuan pendinginan (A) dengan perlakuan pengemasan (B) setelah disimpan selama 6 hari. Dari hasil rerata kadar gula reduksi pada tabel 2 dapat dilihat bahwa jagung manis yang dikemas menggunakan kemasan polietilen (B2), ternyata memberikan kadar gula reduksi tertinggi yaitu sebesar $0,154 \%$. Hal tersebut menunjukkan bahwa penyimpanan jagung manis yang dikemas menggunakan kemasan polietilen (B2) mampu menghambat pembentukan pati dari gula sederhana sehingga kadar gula tetap tinggi. Jenis pengemas polietilen memiliki permeabilitas rendah terhadap $\mathrm{CO}_{2}$ dan $\mathrm{O}_{2}$, sehingga jagung manis yang berada dalam kemasan sulit berhubungan langsung dengan udara yang berada di luar kemasan .

Perlakuan Hydro-cooling (A1) dapat menurunkan kadar gula reduksi hingga 0,091\%, yang disebabkan karena laju perubahan gula sederhana menjadi pati berlangsung lebih cepat. Hal ini didukung oleh pernyataan Muchtadi (1992) bahwa dalam penyimpanan suhu ruang penurunan kadar gula pereduksi maupun non-pereduksi lebih cepat dibandingkan dengan penyimpanan pada suhu rendah. Perubahan kadar gula reduksi jagung manis selama penyimpanan disajikan dalam gambar 3 .
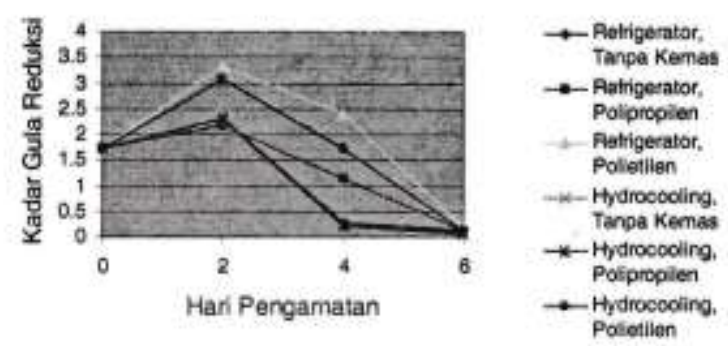

Gambar 3. Perubahan kadar gula reduksi jagung manis selama penyimpanan 


\section{Kadar Air}

Kadar air diamati untuk mengetahui besarnya kehilangan air pada masing-masing perlakuan sehingga dapat ditentukan tingkat kesegaran dan kerenyahannya. Hasil pengamatan rerata kadar air dapat dilihat pada tabel 3 .

Tabel. 3. Rerata kadar air 6 hari setelah disimpan (\%)

\begin{tabular}{|l|c|c|c|c|}
\hline \multirow{2}{*}{$\begin{array}{c}\text { Macam } \\
\text { pendinginan }\end{array}$} & \multicolumn{3}{|c|}{ Macam pengemanan } & \multirow{2}{*}{ Rerata } \\
\cline { 2 - 5 } & $\begin{array}{c}\text { Tumpa } \\
\text { pengemasan } \\
\text { (B0) }\end{array}$ & $\begin{array}{c}\text { Polipropilen } \\
\text { (B1) }\end{array}$ & $\begin{array}{c}\text { Polietilen } \\
\text { (B2) }\end{array}$ & \\
\hline $\begin{array}{l}\text { Refigerator (A0) } \\
\text { Hydro-cooling }\end{array}$ & 73,66 & 75,45 & 76,09 & $75,066 \mathrm{P}$ \\
(A1) & 67,65 & 78,28 & 76,77 & $74,233 \mathrm{p}$ \\
\hline Rerata & $70,655 \mathrm{a}$ & $76,865 \mathrm{a}$ & $76,43 \mathrm{a}$ & $(-)$ \\
\hline
\end{tabular}

Keterangan: Nilai rerata yang diikuti huruf yang sama menunjukkan tidak ada beda nyata berdasarkan uji jarak Duncan pada taraf nyata 95\%. Tanda ( - ) menunjukan tidak ada interaksi antar perlakuan.

Berdasarkan hasil sidik ragam diketahui bahwa tidak ada interaksi antara perlakuan pendinginan dan pengemasan terhadap rerata kadar air jagung manis yang disimpan sampai hari ke-6. Dari nilai rerata kadar air menunjukkan bahwa perlakuan penyimpanan dalam refrigerator tidak berbeda nyata dengan jagung manis pada perlakuan Hydro-cooling. Hal ini berarti perlakuan pendinginan Hydro-cooling dan refrigerator dapat mempertahankan kadar air jagung manis. Transpirasi pada jagung manis yang diberi perlakuan pendinginan refrigerator ataupun dengan perlakuan Hydro-cooling sama kecepatannya.

Dari nilai rerata kadar air menunjukkan bahwa jagung manis yang dikemas dengan plastik polipropilen serta plastik polietilen tidak berbeda nyata dengan perlakuan tanpa kemas. Hal ini berarti pengemasan dapat mempertahankan kadar air jagung manis. Kadar air pada pengemasan polipropilen (B1) cenderung lebih tinggi nilainya yaitu $76,87 \%$ dibanding pengemasan polietilen $(76,43 \%)$. Hal ini disebabkan pada jagung manis yang diletakkan pada wadah yang tertutup rapat akan mengakibatkan molekul air akan keluar dari produk dan bergabung dengan udara dalam kemasan sehingga udara dalam kemasan akan menjadi jenuh, keadaan tersebut akan mengakibatkan transpirasi berjalan lambat. Hal ini didukung oleh pernyataan Tranggono (1990) bahwa hilangnya air dapat dikendalikan dengan cara memberi penghambat yang mampu mencegah kehilangan air. Lebih rendahnya kandungan air jagung manis pada perlakuan tanpa kemas disebabkan karena terjadi proses transpirasi.

\section{Susut Berat}

Hasil pengamatan terhadap susut berat jagung manis disajikan pada tabel 4 ini.
Tabel 4. Susut berat jagung manis pada hari ke-7

\begin{tabular}{|l|c|}
\hline \multicolumn{1}{|c|}{ Perlakuan } & Susut Berat $(\%)$ \\
\hline Refrigerator, tidak dikemas & 6,18 \\
Refrigerator, dikemas polipropilen & 2,65 \\
Refrigerator, dikemas polietilen & 4,18 \\
Hydro-cooling, tidak dikemas & 7,89 \\
Hydro-cooling, dikemas polipropilen & 5,77 \\
Hydro-cooling, dikemas polietilen & 2,68 \\
\hline
\end{tabular}

Pada penyimpanan jagung manis dalam Refrigerator dan dikemas Polipropilen (A0B1) susut beratnya paling sedikit yaitu $2.65 \% \mathrm{Hal}$ ini menunjukkan tingkat kehilangan air yang cukup sedikit disebabkan karena transpirasi dapat dihambat. Terhambatnya proses tersebut karena dalam kemasan kelembapan relatif akan semakin meningkat di sekitar jagung manis maupun terdapatnya aliran udara sehingga transpirasi dapat dihambat (Kader, 1985). Disamping itu jagung manis yang disimpan dalam kemasan tidak langsung berhubungan dengan udara luar sehingga air dalam jagung manis tidak banyak yang hilang. Pada perlakuan Hydro-cooling tanpa pengemasan (A1B0) terjadi susut berat paling besar yaitu $7,89 \%$ hal ini terjadi karena transpirasi tidak dapat dihambat sehinga air dalam jagung manis banyak yang hilang dan susut beratnya menjadi lebih besar.

\section{Persentase Bagian Tidak Layak Konsumsi}

Persentase jagung manis tidak layak konsumsi diamati untuk mengetahui seberapa besar pengaruh pendinginan dan pengemasan terhadap tingkat kelayakan jagung manis yang dikonsumsi oleh manusia

Tabel 5. Persentase bagian tidak layak konsumsi pada hari ke-7

\begin{tabular}{|l|c|}
\hline \multicolumn{1}{|c|}{ Perlakuan } & $\begin{array}{c}\text { Persentase Tidak } \\
\text { Layak Konsumsi } \\
(\%)\end{array}$ \\
\hline Refigerator, tidak dikemas & 85,18 \\
Refigerafor, kemasan polipropilen & 74,07 \\
Refigerator, kemasan polietilen & 59,20 \\
Hydro-cooling, tidak dikemas & 100,00 \\
Hydro-cooling,kemasan polipropilen & 96,29 \\
Hydro-cooling, kemasan polietilen & 74,07 \\
\hline
\end{tabular}

Tabel 5 menunjukkan bahwa jagung manis pada perlakuan Hydro-cooling yang tidak dikemas (A1B0) mencapai persentase tidak layak konsumsi terbesar yaitu $100 \%$ pada hari terakhir pengamatan karena pada jagung manis tanpa kemas terjadi kontak langsung antara $\mathrm{O}_{2}$ dan $\mathrm{CO}_{2}$ di sekitar jagung manis, sehingga kadar air menurun kondisi tersebut akan 
membuka peluang terjadinya pengriputan dan pematangan yang lebih cepat pada bahan bahkan juga pertumbuhan mikrobia, hal ini menyebabkan persentase tidak layak konsumsi yang lebih besar, selain itu kerusakan juga disebabkan karena adanya serangga (semut). Pada penyimpanan jagung manis dalam Refrigerator persentase bagian yang tidak layak konsumsi paling rendah yaitu untuk jenis pengemas Polietilen (A0B2) sebesar 59,02\%, lebih rendahnya persentase tidak layak konsumsi pada perlakuan refigerator dibandingkan dengan perlakuan Hydrocooling disebabkan karena pada perlakuan suhu refrigerator mampu menghambat aktivitas enzim enzim transglikosilase dan glukosil-transferase yang menghambat perubahan gula menjadi pati.

\section{Kenampakan Fisik dan Kesegaran Klobot Serta Uji Organoleptik}

Kenampakan fisik dan kesegaran klobot serta uji organoleptik diamati untuk mengetahui besarnya perubahan fisik jagung manis yang berpengaruh pada kualitas jagung manis. Hasil pengamatan jagung manis yang disimpan lamanya umur simpan dihitung mulai dari keadaan segar sampai jagung mengalami kerusakan yang ditandai terjadinya pembusukan, pencoklatan klobot, berair, berbau serta timbulnya jamur pada permukaan klobot dan ujung jagung manis.

\section{Kesegaran}

Secara umum jagung manis masih segar pada hari ke 3. Penyimpanan dengan jenis pengemas Polietilen dengan perlakuan refrigerator masih segar pada hari ke 7, Hal ini disebabkan pada perlakuan pengemasan dan di simpan dalam refrigerator dalam kemasan polietilen mempunyai permeabilitas yang rendah terhadap $\mathrm{CO}_{2}$ dan $\mathrm{O}_{2}$, dengan demikian kandungan $\mathrm{O}_{2}$ lama kelamaan akan berkurang yang menyebabkan pemasakan menjadi terhambat dan daya simpan menjadi lebih lama (Apandi, 1984), disamping itu perlakuan Refrigerator akan menghambat laju respirasi sehingga mengurangi pengriputan pada bahan. Perlakuan paling buruk adalah pada Hydro-cooling tanpa kemas, pada perlakuan ini jagung manis hanya mampu bertahan sampai hari ke 3 . Hal ini disebabkan karena pada jagung manis tanpa kemas akan terjadi kontak langsung dengan udara luar yang mengakibatkan jagung manis menjadi kering dan kriput, dan pada kondisi ini jagung sudah tidak layak konsumsi.

\section{Keadaan Klobot}

Secara umum jagung manis klobotnya masih hijau pada hari ke 3 . Pengamatan warna klobot terbaik adalah pada pada penyimpanan jagung manis dalam refrigerator yaitu warna klobot masih hijau sampai hari ke 7, hal ini disebabkan pada suhu rendah akan memperlambat pelayuan dan pengeringan. Pengamatan warna klobot terjelek adalah pada jenis pendingin Hydro-cooling yang hanya mampu bertahan selama 3 hari dengan ditandai terbentuknya warna klobot hijau kekuningan serta kecoklatan. Terbentuknya warna coklat pada klobot jagung manis selama penyimpanan dapat disebabkan oleh 2 macam mekanisme, yaitu secara enzimatis dan non enzimatis. Secara enzimatis terjadi peruraian dari struktur sel dimana pada struktur sel yang utuh, senyawa fenol dan enzim fenolase yang bertanggung jawab terhadap timbulnya warna coklat dalam sel normal terletak pada tempat yang terpisah, tetapi jika timbul kerusakan terhadap struktur sel maka fenolase akan berhubungan atau kontak dengan senyawa fenol dan menimbulkan reaksi pencoklatan (Apandi, 1984).

Timbulnya jamur pada permukaan klobot disebabkan karena kondisi yang lembab pada kemasan plastik dan adanya jamur ini menyebabkan terjadinya pembusukan yang diketahui dari perkembangan miselium dan sporangium dari bagian-bagian terinfeksi organisme ini memperoleh jalan masuk melalui lubanglubang alami seperti lentisel atau kerusakan mekanis (Pantastico, 1993). Selain warna aroma jagung manis setelah disimpan berpengaruh terhadap kualitas jagung manis.

\section{Aroma}

Pada perlakuan Hydro-cooling dengan pengemasan baik jenis pengemas polietilen maupun jenis pengemas polipropilen pada akhir pengamatan berbau alkoholik karena persediaan oksigen dalam kemasan berkurang, sehingga pola pembentukan energi berubah dengan cara respirasi anaerob atau fermentasi. Bila jagung manis dalam kemasan melakukan proses fermentasi, maka energi yang diperoleh relatif lebih sedikit. Untuk memenuhi memenuhi kebutuhan energi maka diperlukan substrat (glukosa) dalam jumlah yang cukup karena dalam waktu yang singkat persediaan substrat akan cepat habis yang pada akhirnya akan menyebabkan busuk (Winarno, 1981). 
Tabel.6.Rerata uji organoleptik terhadap rasa

\begin{tabular}{|l|l|l|l|l|l|l|l|l|}
\hline \multirow{2}{*}{ Perlakuan } & \multicolumn{10}{|c|}{ Hari pengamatan } \\
\cline { 2 - 10 } & 0 & 1 & 2 & 3 & 4 & 5 & 6 & 7 \\
\hline A0B0 & 5 & 3,5 & 3,2 & 2,9 & 2,6 & 2,2 & 1,3 & 1,2 \\
\hline A0B1 & 5 & 4,1 & 3,6 & 3,0 & 2,0 & 2,0 & 1,5 & 1,2 \\
\hline A0B2 & 5 & 4,4 & 3,5 & 3,2 & 2,3 & 2,5 & 2,1 & 1,8 \\
\hline A1B0 & 5 & 3,6 & 2,7 & 2,2 & 1,9 & 1,3 & 1 & 1 \\
\hline A1B1 & 5 & 4,1 & 3,4 & 2,6 & 2,5 & 1,7 & 1,3 & 1 \\
\hline A1B2 & 5 & 4,3 & 3,3 & 3,0 & 2,6 & 2,2 & 1,7 & 1,3 \\
\hline
\end{tabular}

Pada tabel 6 menunjukkan bahwa perlakuan pendinginan dan jenis pengemas berpengaruh terhadap kesukaan rasa jagung manis, uji organoleptik ini dilakukan oleh 10 panelis, pada setiap harinya dengan cara mencicipi biji jagung manis. Panelis lebih menyukai rasa jagung manis pada penyimpanan refrigerator dengan kemasan Polietilen (A0B2) Hal ini disebabkan pada perlakuan pendinginan dengan refrigerator mampu menghambat aktivitas enzim UDPG-fruktosa transglikosilasa dan enzim UDPG pati-glukosiltransferasa yang mampu menghambat perubahan gula menjadi pati pada jagung manis, sehingga rasa manis bertahan lebih lama. Pada perlakuan Hydro-cooling tanpa kemas rata rata panelis tidak menyukai jagung manis sejak hari ke 4 , karena tingginya respirasi pada jagung manis tanpa kemas menyebabkan jagung manis tidak berasa manis lagi dan pada kondisi ini jagung manis tampak kriput.

\section{KESIMPULAN}

Berdasarkan hasil penelitian disimpulkan bahwa :

1. Tidak ada interaksi antara perlakuan pendinginan dan pengemasan terhadap umur simpan dan kualitas jagung manis.

2. Perlakuan pendinginan atau pengemasan saja nyata mempengaruhi kandungan pati dan gula reduksi. Pendinginan dalam refrigerator dapat mempertahankan kadar gula reduksi, menekan kadar pati, menurunkan bagian yang tak layak konsumsi, mempertahankan rasa dan mampu memperpanjang umur simpan jagung manis layak konsumsi sampai 6 hari.

3. Pengemasan dengan plastik polietilen nyata dapat mempertahankan kadar gula reduksi dan rasa, tetapi memperpanjang umur simpan jagung manis layak konsumsi sampai 6 hari pada suhu ruang.

\section{DAFTAR PUSTAKA}

Adnan, M., 1992. Aktivitas Air Dan Kerusakan Bahan Makanan, Agritech

Apandi, 1984. Teknologi Buah Dan Sayuran, Alumni Bandung.

Anonim. 2004. Postharvest cooling and handling of sweet corn, www.bae.ncsu.edu/programs/extension/ publicat/posttharv/ag-413-415.

Kader, A.A.,1995. Controlled atmospheres for storage and transport of perishable agricultural comodities. Hort. Report,North Carolina State University.

Koswara, J., 1982, Jagung Diktat Kuliah Tanaman Setahun (Bogor : Departemen Agronomi Fakultas Pertanian IPB).

Muchtadi, D., 1992. Fisiologi Pasca Panen Sayuran dan Buah-buahan, Petunjuk Laboratorium Pusat Antar Universitas Pangan dan Gizi, IPB

Pantastico, Er.B., 1997, Fisiologi Pasca Panen Penanganan dan Pemanfaatan Buah-buahan dan Sayuran Tropika dan Sub Tropika, Diterjemahkan oleh Kamariyani, Gadjah Mada University Press, Yogyakarta.

Palungkun, R. dan A. Budiarti, 1999. Jagung Manis -Baby Corn. Penebar swadaya, Jkt.

Tranggono dan Sutardi, 1989. Biokimia dan Teknologi Pasca Panen, Bahan Pangan dan Gizi, Universitas Gadjah Mada, Yogyakarta.

Winamo, F.G.1981. Fisiologi Lepas Panen. Sastra Hudaya, Jakarta. 97 hal.

Zakaria.A., Pengaruh Perlakuan Udara Termodifikasi $(\mathrm{N2}: \mathrm{O} 2: \mathrm{CO} 2=90: 3: 7)$ Pada Penyimpanan Jagung Manis, Skripsi Mahasiswa Universitas Gajah Mada Yogyakarta.2001. 